\title{
Cannabis som medisin
}

\author{
Cannabis kan gi nedsatt helse og økt risiko for sykdom. Men det er også godt dokumentert at stoffet har \\ effekt ved en rekke sykdommer. Det er imidlertid tvilsomt om medisinsk bruk av cannabis er et argument \\ for eller imot legalisering.
}

Jørgen G. Bramness

j.g.bramness@medisin.uio.no

Vår forståelse av risikoen ved cannabisbruk er blitt mer nyansert de senere tiårene. Det er ikke lenger slik at man med nødvendighet blir psykotisk eller får varig nedsatte kognitive evner av å røyke hasj. Selv om den relative risikoen ved cannabisbruk er signifikant forhøyet, skjønner vi nå at den absolutte faren er mer begrenset.

Cannabis har vært kjent som medisinplante i flere tusen år og blir i mange land brukt som det også i dag. Spesielt er virkningen av ulike cannabisprodukter undersøkt hos alvorlig syke og døende, hos kronisk syke der annen behandling svikter og ved tilstander der man helt mangler behandling. Noen eksempler på slik forskning følger her.

Cannabis kan brukes mot kvalme hos cellegiftbehandlede. Moderne kjemoterapi er ofte aggressiv, og kvalme og oppkast kan være vanskelig å kontrollere. Selv om det er utviklet flere effektive legemidler mot cellegiftindusert kvalme, vil ikke alle bli tilfredsstillende hjulpet av disse. Det er gjort relativt mange og gode studier på hvilken plass cannabis skal ha i denne behandlingen. Tidligere er stoffet i de fleste studiene blitt sammenliknet med eldre kvalmestillende midler og er blitt bedømt som bedre enn disse. Mange pasienter foretrekker cannabisproduktene, kanskje også på grunn av den stemningshevende effekten (1). Også nyere oversikter bekrefter at cannabinoider er overlegne i behandlingen av cellegiftindusert kvalme $(2,3)$.

Man har undersøkt effekten av cannabisprodukter ved alvorlige smerter som følge av kreftsykdom, kirurgi og sykdommer i sentralnervesystemet. Også her finnes det relativt mange studier med god design som viser at stoffet er effektivt $(4,5)$. Noen stiller imidlertid spørsmål ved om cannabis og cannabinoider er mer effektive enn tradisjonelle smertestillende medisiner, andre tviler på om de vil få en utbredt bruk på grunn av misbruksfaren (6).

Pasienter med multippel sklerose er ofte plaget av invalidiserende indre uro, skjelvinger, smerter og muskelkramper. Uroen lindres ikke av cannabis eller cannabisprodukter (7). Når det gjelder smerter, er dette gjennomgått $i$ en oversikt fra 2007 med seks publiserte studier (4). Cannabinoider viste seg å være bedre enn placebo når det gjaldt smertelindring. Cannabis kan også ha effekt på muskelkramper. Den viktigste bivirkningen var svimmelhet. Et ekstrakt fra cannabisplanten er godkjent for bruk ved spastisitet ved multippel sklerose i Norge.

Anoreksi, avmagring, kvalme og smerter kan være del av det som kalles aidsrelatert svakhet, en tilstand som var vanligere før man hadde moderne hivbehandling. Canna-

\section{«Cannabis har vært kjent som medisinplante i flere tusen år og blir i mange land brukt som det også i dag»}

bis ble introdusert som legemiddel fordi man kjente til sukkerhungeren relatert til midlet. Det er vist at cannabis kan ha en effekt her (8).

Det hevdes at cannabis har effekt ved sykdommer som bipolar lidelse, Tourettes syndrom, autisme, migrene og AD/HD. Dokumentasjonen er imidlertid svak, og det er ikke anerkjent at stoffet kan anvendes på disse indikasjonene. Det foregår imidlertid forskning rundt bruk av cannabis, cannabisliknende stoffer eller substanser som på en eller annen måte interagerer med det endocannabinoide systemet for så ulike tilstander som psykose, autoimmune sykdommer og Alzheimers sykdom.

\section{En medisinsk retorikk}

En del cannabisaktivister hevder at stoffets medisinske anvendelighet taler for legalisering. Medisinsk marihuana er i USA blitt brukt som brekkstang for dette, men til tross for det som er beskrevet over, hviler mye av den medisinske bruken på et for svakt empirisk grunnlag. På den annen side skal ikke moralisme og frykt for misbruk hindre oss i å gi effektiv behandling til pasienter som trenger det. Vi må vurdere den foreliggende kunnskapen og dømme ut fra dette. Som for andre midler må cannabis brukt som medisin være en avveining av effekt mot bivirkninger og risiko (også for misbruk), på bakgrunn av data fra gode undersøkelser. Og noen studier er gode nok og gir et kunnskapsgrunnlag for effekten cannabis har ved en del tilstander.

Flere har tatt til orde for at vi må få cannabis på resept. Dette kan skyldes at $\mathrm{FN}$-avtaler åpner for bruken av psykoaktive stoffer når det er medisinsk nødvendig. Ulike land har tolket dette med medisinsk nødvendighet forskjellig, men i hvert fall i USA og Canada har ikke dette betydd at leger må stå for forskrivningen (9).

I Europa og i Norge er det urealistisk å tenke seg at cannabis vil kunne selges gjennom apotek. Alle produkter til medisinsk bruk må ha farmasøytisk kvalitet. Man må kunne angi hvor mye det er av alle stoffene i produktet og hvor mye pasienten får i seg hver gang. De som røyker cannabis, titrerer seg ofte frem til ønsket virkning selv. Dette kan oppleves som rett doseringsform for noen, men er neppe godt nok for en apotekvare. Rus som sådan er ikke diskvalifiserende, men inntak gjennom røyking ville innebære et helt nytt doseringsprinsipp.

Cannabis som medisin er tilgjengelig i prinsipielt tre forskjellige former. For det første brukes selve planteproduktet, og da oftest marihuana. Her forsøker man å angi hvor mye $\Delta$-9-tetrahydrocannabinol (THC) og cannabidiol (CBD) som er til stede (fig 1). For det andre lages ekstrakter som appliseres gjennom nesespray (nabiximols (Sativex)), registrert for medisinsk bruk i Norge (10), eller stoffer som kan røykes (Bediol). For begge disse produktene vil det være krevende å vite hvor mye aktive stoffer som finnes i produktet, selv om Sativex har oppnådd så høy nøyaktighet at produktet er godkjent til medisinsk bruk. For det tredje brukes også syntetiske varianter. I Norge er det syntetisk fremstilte dronabinol (Marinol) blitt brukt medisinsk. 


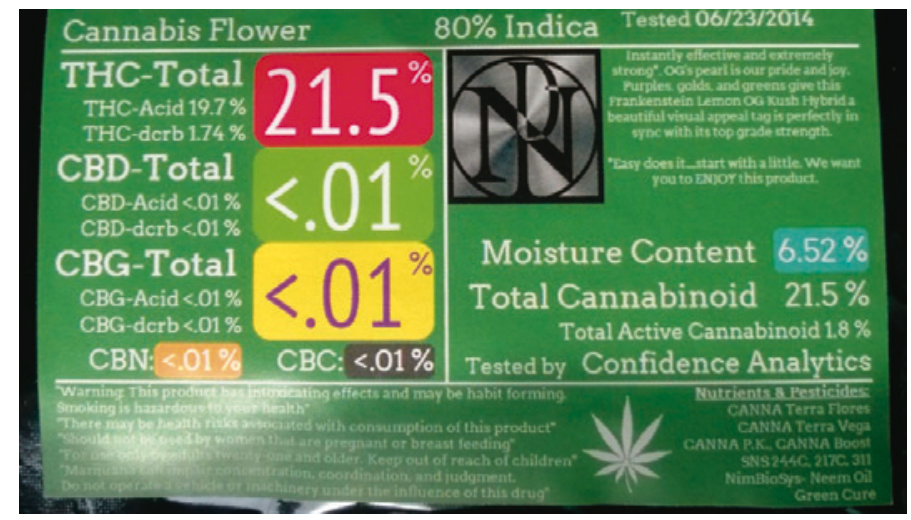

Figur 1 Cannabis solgt i USA kommer nå med varedeklarasjon, hvor mengde $\Delta$-9-tetrahydrocannabinol (THC) og cannabidiol (CBD) angis. Foto: Caleb Banta-Green

Noen har tatt til orde for at leger kunne undersøke dem som ønsker å bruke cannabis - for å se hvem som tåler det og hvem som ikke tåler det - og så eventuelt skrive ut resept (11). At leger kan plukke ut dem med sårbarhet for psykose for eksempel og gi andre grønt lys, er naivt. Det er riktig at sårbarhetsfaktorer spiller en stor rolle for utvikling av psykose (12), og rett nok er psykotisk dekompensering en relativt sjelden affære (13) - risikoen for å si noe galt er derfor minimal. Men vi mangler gode indikatorer for å plukke ut sårbare individer, og det ville bryte med medisinske prinsipper å skulle gi noen en «rusgodkjenning». Å gi et rusmiddel en medisinsk kontekst er noe vi kjenner fra forbudstiden, da leger skrev ut alkohol på tvilsomme pseudoindikasjoner. Den gang forbød man noe og legene ble en utvei, men vi leger ønsker vel neppe en gjentakelse av dette.

Jeg får ofte telefoner fra pasienter som bruker cannabis mot forskjellige plager som kan være betydelige. Jeg kan ikke avvise at cannabisprodukter eller derivater vil kunne hjelpe dem. Tvert imot støtter jeg dem ofte. Delvis finnes det gode randomiserte, kontrollerte studier som viser effekt for noen lidelser, men manglende forskning på andre områder er ikke noe bevis mot effekt. På den annen side problematiserer jeg dette med røyking, som antakelig gir økt risiko for både kols og kreft (14), og dette med å bruke cannabisderivater med unøyaktig dosering.

Rett nok bruker selgere av medisinsk cannabis i USA en medisinsk diskurs, men det blir ikke god medisin av den grunn. Vi må forsøke å behandle cannabisprodukter som annen medisin. Det er tvilsomt om medisinsk bruk av cannabis er et argument for eller imot liberalisering eller legalisering - like lite som bruk av morfin ved akutt hjerteinfarkt eller smertetilstander er et argument for frislipp av opioider.

En liberalisering eller legalisering av cannabis lenkes ofte opp til et ønske om regulering av bruken gjennom offentlige ordninger $(11,15)$. Man ønsker salg gjennom et rusmonopol. Om man går inn for en legalisering, tror jeg dette er en fornuftig utvikling. Men jeg tror ikke leger har en rolle i denne viktige forebyggende delen av en slik fremtid.

\section{Jørgen G. Bramness (f. 1962}

er spesialist i psykiatri, professor og forskningsdirektør ved Senter for rus- og avhengighetsforskning (SERAF), Universitetet i Oslo. Forfatter har fylt ut ICMJE-skjemaet og oppgir ingen interessekonflikter.
Litteratur

1. Tramèr MR, Carroll D, Campbell FA et al. Cannabinoids for control of chemotherapy induced nausea and vomiting: quantitative systematic review. BMJ 2001; 323: 16-21.

2. Ware MA, Daeninck P, Maida V. A review of nabilone in the treatment of chemotherapy-induced nausea and vomiting. Ther Clin Risk Manag 2008 4: $99-107$

3. Machado Rocha FC, Stéfano SC, De Cássia Haiek $\mathrm{R}$ et al. Therapeutic use of Cannabis sativa on chemotherapy-induced nausea and vomiting among cancer patients: systematic review and meta-analysis. Eur J Cancer Care (Engl) 2008; 17: $431-43$

4. Iskedjian M, Bereza B, Gordon A et al. Meta-analysis of cannabis based treatments for neuropathic and multiple sclerosis-related pain. Curr Med Res Opin 2007; 23: 17-24

5. Lynch ME, Campbell F. Cannabinoids for treatment of chronic non-cancer pain; a systematic review of randomized trials. $\mathrm{Br} \mathrm{J}$ Clin Pharmacol 2011; 72: 735-44.

6. Campbell FA, Tramèr MR, Carroll D et al. Are cannabinoids an effective and safe treatment option in the management of pain? A qualitative systematic review. BMJ 2001; 323: 13-6.

7. Mills RJ, Yap L, Young CA. Treatment for ataxia in multiple sclerosis. Cochrane Database Syst Rev 2007: 1: CD005029.

8. Beal JE, Olson R, Lefkowitz L et al. Long-term efficacy and safety of dronabinol for acquired immunodeficiency syndrome-associated anorexia. J Pain Symptom Manage 1997; 14: 7-14.

9. Mead AP. International control of cannabis. In: Pertwee RG, editor. Handbook of cannabis. Oxford: Oxford University Press, 2014

10. Gramstad L, Sagabråten AS. Cannabislegemiddel i Norge - grunnlaget for godkjenning. Tidsskr Nor Legeforen 2012; 132: 2598-9.

11. Pedersen W. Hasj på resept. Aftenposten 9.11.2009.

12. Bramness JG, Gundersen OH, Guterstam J et al. Amphetamine-induced psychosis-a separate diagnostic entity or primary psychosis triggered in the vulnerable? BMC Psychiatry 2012; 12: 221.

13. Zammit S, Allebeck P, Andreasson S et al. Self reported cannabis use as a risk factor for schizophrenia in Swedish conscripts of 1969: historical cohort study. BMJ 2002; 325: 1199.

14. Hall W. What has research over the past two decades revealed about the adverse health effects of recreational cannabis use? Addiction 2015; 110: $19-35$

15. Room R. Legalizing a market for cannabis for pleasure: Colorado, Washington, Uruguay and beyond. Addiction 2014; 109: 345-51.

Mottatt 20.11. 2014 og godkjent 22.12. 2014

Redaktør: Erlend Hem. 